\title{
Apple growing potentials in Europe. 3. Northern limits
}

\section{H. G. KRONENBERG}

Department of Horticulture, Wageningen Agricultural University, P.O. Box 30, NL 6700 AA Wageningen, Netherlands

Received 7 October 1987; accepted 28 November 1988

\begin{abstract}
The northern production limits were determined of four apple cultivars: 'White Transparent', 'Cox's Orange Pippin', 'Golden Delicious', and 'Granny Smith'. Reactions of an apple cultivar to temperatures are: a first temperature-sensitive period in which a certain temperature sum must be reached; a second less sensitive period in which temperatures must reach a certain level during a certain period and a third sensitive period. A model was developed in which temperatures of the most northern growing place were brought in and this model was afterwards checked with data of other growing places. When differences between measured and estimated values were acceptable, the model was used to calculate whether ripening of an apple cultivar could be expected in a specific area. Thus the northern production limits could be determined.
\end{abstract}

Keywords: apple, model, area limits

\section{Introduction}

In literature on climatic limits of apple production in Europe, only two not too accurate references were found. Thran (1959) mentioned that the temperature requirements for growth of apple trees are 170 days above $5{ }^{\circ} \mathrm{C}$. In Winkler-Prins (1959), the northern limits of fruit trees are outlined on a map, however, not specified into apple, pear, cherry, etc. Main results of both references are plotted in Figure 1. These publications do not indicate whether the limits hold for growing trees or fruits. It is supposed that demands for commercial fruit production are higher than for growing trees only.

In this paper it is tried to make clear, or at least suggest an explanation, why the limits of apple production are where they are. And because it is known that not one limit holds for all apple cultivars, four cultivars were chosen:

- very early 'White Transparent',

Publication No 547, Department of Horticulture, Agricultural University, Wageningen, Netherlands. 


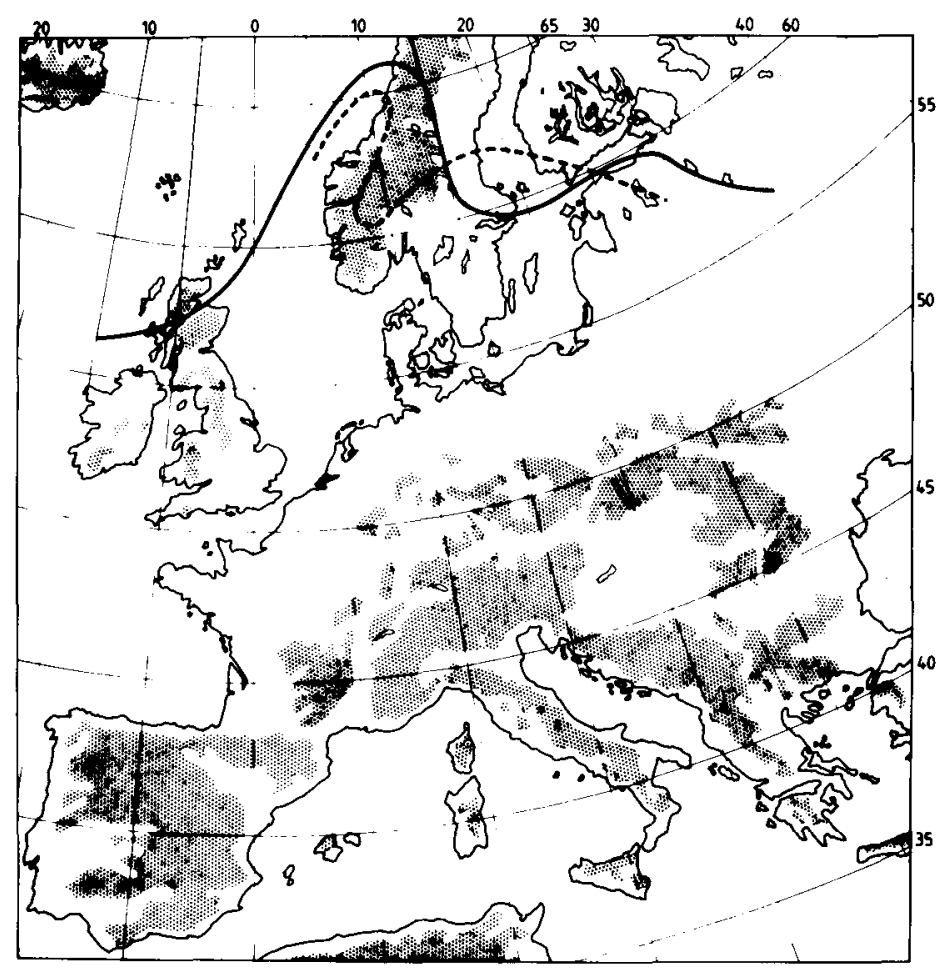

Fig. 1. Northern limits of growth of apple trees: — after Thran (1959), - - after Winkler Prins (1959).

- mid-season 'Cox's Orange Pippin',

- late 'Golden Delicious', and

- very late 'Granny Smith'.

\section{Designing a model}

The two most important plant growth determining factors are light and temperature. Landsberg (1979) states that radiation especially influences the yield. Kronenberg (1988) found that temperature is of utmost importance for apple growing. Because of that, the northern limits for production of apples also are determined by prevailing temperatures only. Kronenberg worked with base temperatures below which no growth was observed and with mean day temperatures. He calculated temperature sums by adding the per day temperatures above the base temperatures and used one month as a relevant period.

Sometimes rather low base temperatures of $6{ }^{\circ} \mathrm{C}$ or lower were found, as observed earlier for apple (Kronenberg, 1985a) and for other plants (Kronenberg, 1985b). Mean day temperatures above $6{ }^{\circ} \mathrm{C}$ (or lower) were added and in most cases high temperature sums were found. These temperature sums and a specific 
minimum (base) temperature were used as variables in the model. Low base temperatures prevail shortly after flowering and before picking. In between, high base temperatures $\left(7-26^{\circ} \mathrm{C}\right)$ together with rather low temperature sums are observed. High 'base' temperatures in this context are related to long-lasting processes on which only very high temperatures have a perceptible influence.

The high base temperatures require a hot spell so that at least a few days with high temperature contribute to reach the required temperature sum. Kronenberg (1988) also found that the higher the prevailing temperatures, the higher 'base' temperatures were found. The phenomenon that the period between flowering and picking is hardly shortened for apples in hotter climates is reported by Winter (1981).

Therefore, when a high 'base' temperature was found in a certain month, that temperature was used in the model for a period of 30 days. In the model used for estimating the northern production limits, in period 1 and 4 , beside these base temperatures a specified temperature sum is used; in period 2 and 3 , mean temperature during a specified period is used (period numbering taken from Table 6).

\section{From the basic model to a model for a specified cultivar}

The most northern fruit growing station with data available of flowering, picking and production were used (Table 1). Base temperatures were taken from Kronenberg (1988), temperature sums were calculated from other sources gathered for but not used in Kronenberg (1988).

'White Transparent' can be grown in Blangstedgaard and data of this station and of Belridge airport are used (Tables 2 and 3). To find the northern production limit of 'White Transparent', differences between reported data of flowering and picking and those calculated in 5 places were checked (Table 4). Similar information on 'Cox's Orange Pippin', 'Golden Delicious' and 'Granny Smith' is given in Tables 2, 3 and 4.

Table 1. Fruit growing locations and meteorological stations.

\begin{tabular}{llll}
\hline $\begin{array}{l}\text { Place of apple } \\
\text { observations }\end{array}$ & $\begin{array}{l}\text { Meteorological } \\
\text { station }\end{array}$ & $\begin{array}{l}\text { Estimated distance } \\
\text { between place of } \\
\text { observation and meteo- } \\
\text { rological station }\end{array}$ & $\begin{array}{l}\text { Daily temperature } \\
\text { is based on }\end{array}$ \\
$\begin{array}{l}\text { Blangstedgaard } \\
\left(55^{\circ} 40^{\prime} \text { north }\right.\end{array}$ & $\begin{array}{l}\text { Belridge airport } \\
\text { Odense }\end{array}$ & $5 \mathrm{~km}$ & (minimum + \\
$10^{\circ} 40^{\prime}$ east) & maximum): 2 \\
$\begin{array}{l}\text { Denmark } \\
\text { Wilhelminadorp }\end{array}$ & $\begin{array}{l}\text { Koninklijk Neder- } \\
\text { lands Meteorolo- }\end{array}$ & $20 \mathrm{~km}$ & \\
$\begin{array}{l}51^{\circ} 30^{\prime} \text { north } \\
3^{\circ} 46^{\prime} \text { east) }\end{array}$ & $\begin{array}{l}\text { gisch Instituut } \\
\text { Netherlands }\end{array}$ & \begin{tabular}{l} 
Station Vlissingen \\
\hline
\end{tabular}
\end{tabular}




\section{H. G. KRONENBERG}

Table 2. Base temperatures and temperature sums for apple.

April May June July August Sept. Oct. Nov.

White Transparent (Blangstedgaard)

$\begin{array}{lrrrr}\text { Base temperature }\left({ }^{\circ} \mathrm{C}\right) & 0 & 18 & 18 & 2 \\ \text { Temperature sum }\left({ }^{\circ} \mathrm{C} \text { days }\right) & & & & \\ 1961 & 317 & 3 & 2 & 26 \\ 1962 & 71 & 2 & 0 & 279 \\ 1963 & 119 & 1 & 0 & 251 \\ 1964 & 223 & 3 & 1 & 115 \\ 1966 & 250 & 7 & 5 & 113 \\ \text { mean } & 196 & 3 & 2 & 157\end{array}$

Cox's Orange Pippin (Blangstedgaard)

$\begin{array}{lrrrrrr}\text { Base temperature }\left({ }^{\circ} \mathrm{C}\right) & 7 & 15 & 18 & 16 & 0 & 4 \\ \text { Temperature sum }\left({ }^{\circ} \mathrm{C} \text { days }\right) & & & & & & \\ 1960 & 52 & 24 & 4 & 24 & 336 & 0 \\ 1961 & 83 & 29 & 5 & 7 & 409 & 0 \\ 1962 & 6 & 11 & 0 & 2 & 363 & 81 \\ 1963 & 42 & 16 & 2 & 27 & 367 & 0 \\ 1964 & 80 & 17 & 4 & 18 & 322 & 0 \\ 1965 & 0 & 6 & 0 & 4 & 407 & 84 \\ 1966 & 63 & 38 & 10 & 8 & 359 & 0 \\ 1970 & 13 & 70 & 8 & 22 & 340 & 0 \\ 1971 & 98 & 18 & 18 & 35 & 328 & 0 \\ 1972 & 61 & 16 & 32 & 24 & 295 & 0 \\ 1973 & 82 & 41 & 28 & 34 & 260 & 0 \\ 1976 & 41 & 42 & 31 & 48 & 368 & 0 \\ \text { mean } & 52 & 27 & 12 & 21 & 346 & 14\end{array}$

Golden Delicious (Blangstedgaard)

\begin{tabular}{lrrrrrrr} 
Base temperature $\left({ }^{\circ} \mathrm{C}\right)$ & 8 & 16 & 20 & 14 & 14 & 0 & 0 \\
Temperature sum $\left({ }^{\circ} \mathrm{C}\right.$ days $)$ & & & & & & & \\
1960 & 47 & 12 & 0 & 63 & 20 & 204 & 0 \\
1961 & 56 & 16 & 1 & 29 & 33 & 341 & 0 \\
1963 & 44 & 8 & 0 & 55 & 6 & 284 & 50 \\
1964 & 70 & 9 & 0 & 48 & 12 & 224 & 0 \\
1965 & 0 & 2 & 0 & 22 & 14 & 285 & 74 \\
1966 & 39 & 23 & 2 & 34 & 16 & 280 & 0 \\
1970 & 18 & 51 & 2 & 60 & 15 & 243 & 0 \\
1971 & 81 & 10 & 2 & 75 & 5 & 246 & \\
1972 & 50 & 9 & 12 & 57 & 3 & 220 & 0 \\
1973 & 73 & 28 & 8 & 73 & 29 & 152 & 0 \\
1974 & 71 & 11 & 0 & 63 & 27 & 193 & 0 \\
1976 & 41 & 30 & 10 & 0 & 5 & 201 & 0 \\
mean & 49 & 17 & 3 & 56 & 15 & 244 & 10 \\
\hline
\end{tabular}


Table 2. Continued.

$$
\text { April May June July August Sept. Oct. Nov. }
$$

Granny Smith (Wilhelminadorp)

\begin{tabular}{lrrrrrrrr} 
Base temperature $\left({ }^{\circ} \mathrm{C}\right)$ & 3 & 0 & 15 & 19 & 18 & 16 & 10 & 0 \\
Temperature sum $\left({ }^{\circ} \mathrm{C}\right.$ days $)$ & & & & & & & & \\
1971 & 0 & 308 & 10 & 11 & 9 & 7 & 81 & 97 \\
1972 & 0 & 306 & 3 & 9 & 2 & 0 & 32 & 0 \\
1973 & 0 & 213 & 46 & 7 & 28 & 30 & 48 & 50 \\
1974 & 27 & 362 & 18 & 0 & 6 & 3 & 2 & 31 \\
1975 & 0 & 296 & 26 & 8 & 58 & 18 & 31 & 0 \\
mean & 5 & 297 & 21 & 7 & 21 & 12 & 39 & 36 \\
\hline
\end{tabular}

Table 3. Parameters of the model for apple.

\begin{tabular}{lllll}
\hline Period & $\begin{array}{l}\text { Base temperature } \\
\left({ }^{\circ} \mathrm{C}\right)\end{array}$ & $\begin{array}{l}\text { T-sum } \\
\left({ }^{\circ} \mathrm{C} \text { days }\right)\end{array}$ & $\begin{array}{l}\text { Mean temperature } \\
\left({ }^{\circ} \mathrm{C}\right)\end{array}$ & $\begin{array}{l}\text { Length of period } \\
\text { (days) }\end{array}$
\end{tabular}

\section{White Transparent}

$\begin{array}{rrrrr}1 & 0 & 196 & - & - \\ 2 & - & - & 14.5 & 30 \\ 3 & - & - & 16.2 & 30 \\ 4 & 2 & 157 & - & -\end{array}$

Cox's Orange Pippin

$\begin{array}{rrrrr}1 & - & - & 11.2 & 10 \\ 2 & - & - & 14.5 & 30 \\ 3 & - & - & 16.2 & 30 \\ 4 & - & - & 15.5 & 30 \\ 5 & 0 & 360 & - & -\end{array}$

\section{Golden Delicious}

\begin{tabular}{|c|c|c|c|c|}
\hline 1 & - & - & 11.2 & 10 \\
\hline 2 & - & - & 14.5 & 30 \\
\hline 3 & - & - & 16.2 & 30 \\
\hline 4 & - & - & 15.5 & 30 \\
\hline 5 & - & - & 12.5 & 30 \\
\hline 6 & 0 & 254 & - & - \\
\hline \multicolumn{5}{|c|}{ Granny Smith } \\
\hline 1 & 0 & 302 & - & - \\
\hline 2 & - & - & 16.4 & 30 \\
\hline 3 & - & - & 18.5 & 30 \\
\hline 4 & - & - & 18.1 & 30 \\
\hline 5 & - & - & 15.9 & 30 \\
\hline 6 & - & - & 11.5 & 30 \\
\hline 7 & 0 & 36 & - & - \\
\hline
\end{tabular}




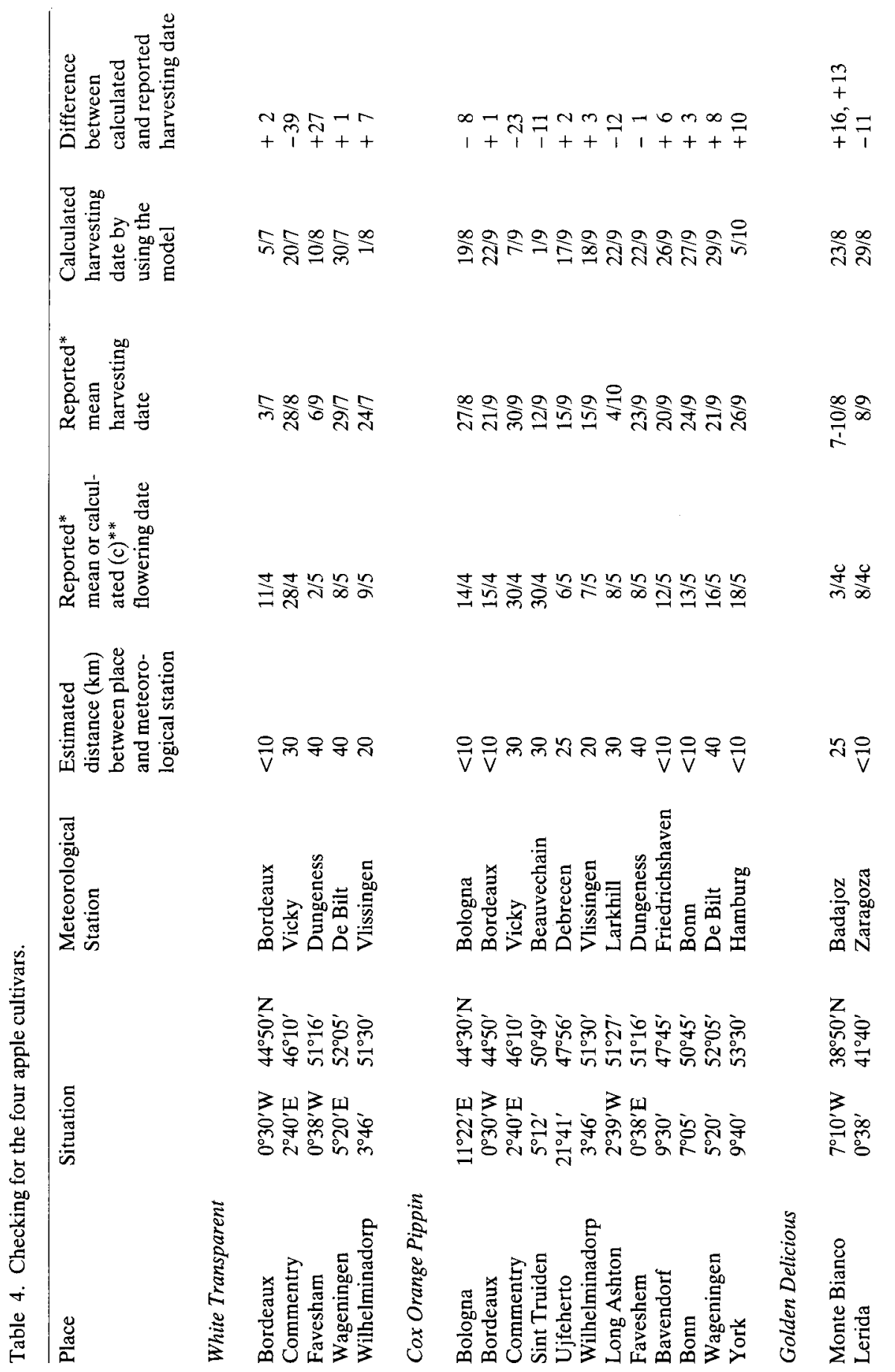


$1+1 \frac{1}{1}+\frac{1}{1} 11++1$
man

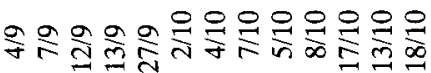

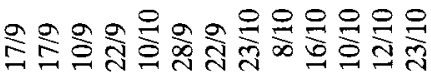

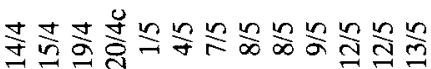

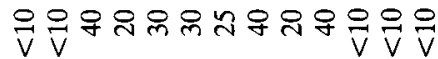

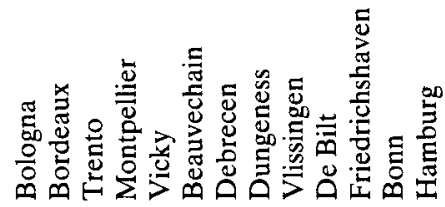

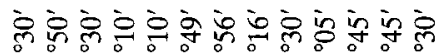

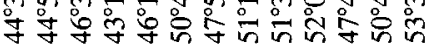

피

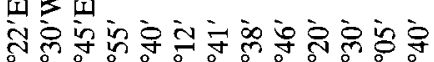

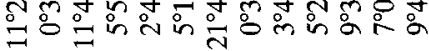

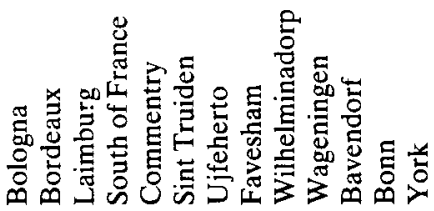

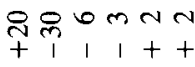

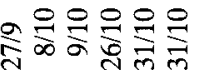

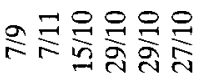

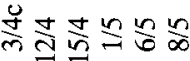

กํํำㅇํำ

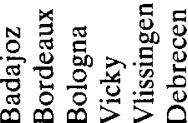

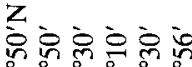

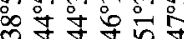

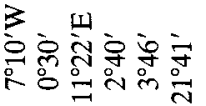

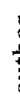

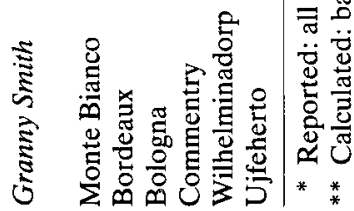


Table 5. Goodness of fit for the model used for four apple cultivars.

\begin{tabular}{lllll}
\hline Cultivar & \multicolumn{2}{l}{$\begin{array}{l}\text { Added differences } \\
\text { (days) (Table 4) }\end{array}$} & \multicolumn{2}{l}{ Frequency of differences } \\
\cline { 3 - 4 } & & & - & + \\
White Transparent & -39 & +37 & 1 & 4 \\
Cox's Orange Pippin & -54 & +33 & 5 & 7 \\
Golden Delicious & -88 & +42 & 9 & 6 \\
Granny Smith & +39 & +26 & 3 & 3 \\
\hline
\end{tabular}

\section{Discussion of the model per cultivar}

The lists of temperature sums given in Table 2 illustrate the irregularity of the WestEuropean weather when studied per month.

In comparing the model for the cultivars (Table 3 ), there are similarities and differences. 'White Transparent' and 'Granny Smith' have a first period with a temperature sum. The last period has a temperature sum for all cultivars. The whole fixed period in between varies from 60-150 days, with the shortest period for 'White Transparent' and the longest for 'Granny Smith'.

The goodness of fit was checked by:

- the sum of the differences in days between reported and calculated harvesting date,

- the direction (- or + ) of these differences (Table 5).

With differences being small and not 'one-sided', results for 'White Transparent', 'Golden Delicious' and 'Granny Smith' were acceptable. For 'Cox's Orange Pippin', this was achieved after introducing a 10-day period with $11.2^{\circ} \mathrm{C}$, instead of a base temperature of $7{ }^{\circ} \mathrm{C}$ and a temperature sum period.

For all four cultivars, on average a somewhat earlier picking date was found with the model. It is possible that this is introduced because the most northern location of reference was chosen.

\section{Using the model}

As a result of the foregoing, the northern production limits were estimated. For that, temperatures were taken from a number of places mentioned in Thran \& Broekhuizen (1965); the moment of flowering was based on Kronenberg (1985a) (Table 6 for 'White Transparent'). Based on these results the lines of the map (Figure 2) were drawn.

The map shows that the four cultivars have different northern production limits. In West-Europe, lines come closer to each other than in the eastern part. The english climate has a long, not too cold season whereas in eastern Europe a shorter and warmer period for growing apples is found. There is a fair agreement between the lines in Figures 1 and 2.

In Norway, there is apple production north of the borderlines given in Figure 2. 


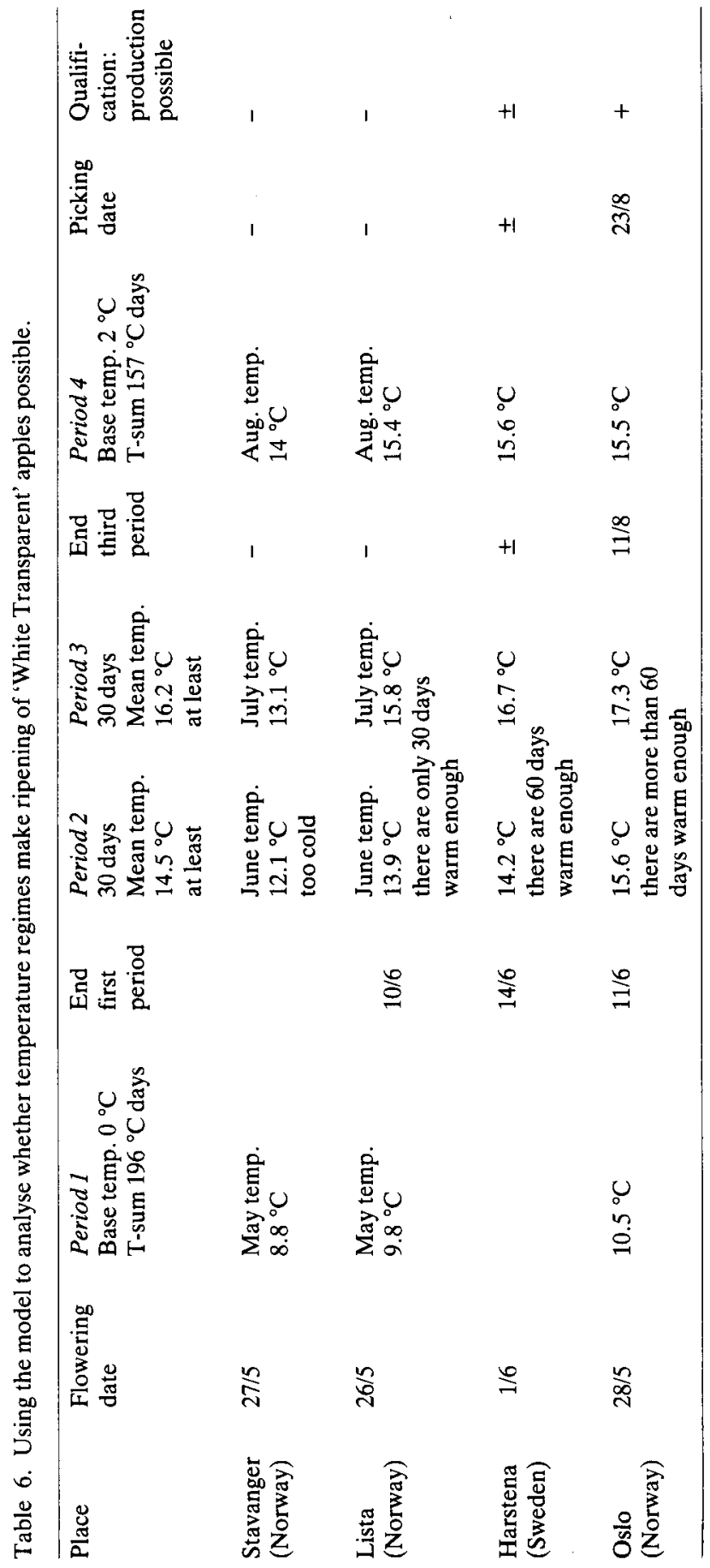




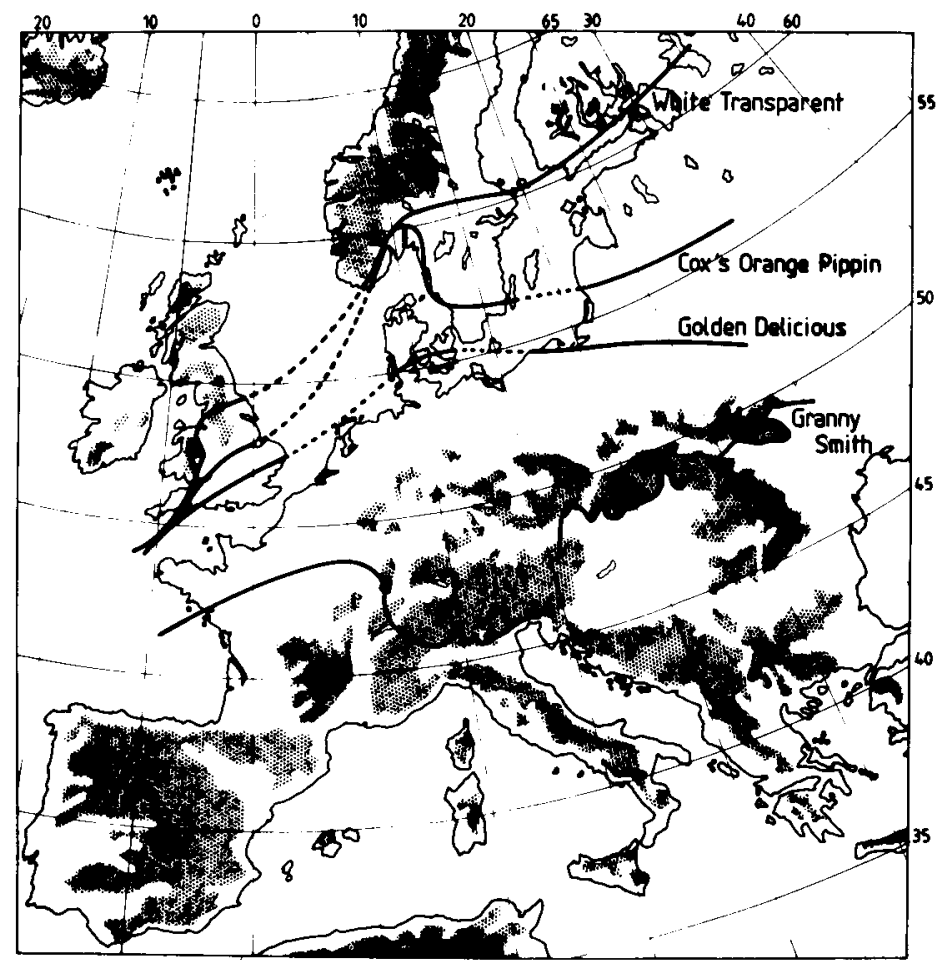

Fig. 2. Northern limit of production of four apple cultivars in Europe.

Cultivars used there may have lower temperature requirements than 'White Transparent', and micro-climatic conditions can favour production as for instance the terraced apple growing on the northern side of the Sognefjord. In England, apple growing shifts from commercial fruitfarms to private gardens above the lines.

The limits for production are seldom sharp and especially if prices are as high as, for instance, in Norway, production can be profitable even if ripening is not most excellent. The last phenomenon holds also for 'Granny Smith' at Wilhelminadorp, in the Netherlands.

\section{Acknowledgements}

I like to thank R. P. M. Buiskool for making all the calculations and H. H. W. van Lent for drawing the maps.

\section{References}

Kronenberg, H. G., 1985a. Apple growing potentials in Europe. 2. Flowering dates. Netherlands Journal Agricultural Science 33: 45-52. 
Kronenberg, H. G., 1985b. Flowering in Forsythia $\times$ intermedia 'Spectabilis' The Garden 110: 160-162.

Kronenberg, H. G., 1988. Temperature requirement for growth and ripening of apples. Netherlands Journal of Agricultural Science 36: 23-33.

Landsberg, J. J. 1979. Limits to apple yields imposed by weather. In: Proceedings 75th Anniversary Meeting of the Association of Applied Biologists, Reading, UK, 75 pp.

Thran, P. 1959. Die Klimatische Grundlagen des Landbaues in Zentraleuropa. Über Methoden und Ergebnisse. S.NK 0096/VK/Wetteramt Schleswig, Kiel, 23 pp.

Thran, P. \& S. Broekhuizen, 1965. Agroclimatic atlas of Europe. Pudoc, Wageningen.

Winkler Prins, 1959. General Encyclopedia, Vol. VIII (map between p. 752-753). Elsevier, Amsterdam (in Dutch).

Winter, F., 1981. Lucas' Anleitung zum Obstbau, p. 45. Eugen Ulmer, Stuttgart. 